\title{
Influence of in vitro Salinity on Growth and some Element Contents of Three Grape (Vitis vinifera L.) Cultivars
}

Abulfadl, Eman A. ${ }^{2}$; M.M. Shaaban ${ }^{1}$; A. M.A. El-Sese ${ }^{1}$ and Alia H.I. El-Hawary ${ }^{2}$

${ }^{1}$ Fruit Department, Faculty of Agriculture, Assiut University

${ }^{2}$ Horticulture Research Institute, A.R.C., Egypt

\section{Abstract:}

Influences of in vitro salinity in form of sodium chloride $(\mathrm{NaCl})$ and calcium chloride $\left(\mathrm{CaCl}_{2}\right)$ on growth and element contents of three grape cultivars (Thompson Seedless, Red Roomy and Beauty Seedless) were investigated. Shoot tip explants were cultured on Murashige and Skoog (MS) medium containing 1.0 $\mathrm{mg} / \mathrm{l}$ benzylaminopurine (BAP). The experiment was conducted with four levels of $\mathrm{NaCl}(0,50,85$ and $120 \mathrm{mM})$ and four levels of $\mathrm{CaCl}_{2}(0,1,5$ and $10 \mathrm{mM})$ and mixture of both salts with three levels $\left[0,60\left(50 \mathrm{NaCl}+10 \mathrm{CaCl}_{2}\right)\right.$ and $90(85$ $\left.\mathrm{NaCl}+5 \mathrm{CaCl}_{2}\right) \mathrm{mM}$ ]. The results showed that the growth parameters (proliferation, plantlet height, number of leaves, number of nodes, internode length, fresh and dry weight) significantly decreased with increasing $\mathrm{NaCl}$ concentrations up to $120 \mathrm{mM}$ compared to the control treatment. However, application of $\mathrm{CaCl}_{2}$ treatments counteracted this inhibitory effect on the growth parameters at $5 \mathrm{mM}$. $\mathrm{CaCl}_{2}$ supply increased shoot $\mathrm{Ca}^{2+}$ content and decreased shoot $\mathrm{Na}^{+}$content. Increasing $\mathrm{NaCl}$ and $\mathrm{CaCl}_{2}$ concentrations in the culture medium increased the contents of $\mathrm{Na}^{+}, \mathrm{Ca}^{2+}$, whereas $\mathrm{K}^{+}$content decreased compared to the control.

Keywords: Vitis vinifera, $\mathrm{NaCl}, \mathrm{CaCl}_{2}$, in vitro

Received on: 29/4/2014

Referees: Prof. Ayman K. Ahmed
Accepted for publication on: 15/5/2014

Prof. Mohamed M. A. Harhash 


\section{Introduction:}

Salinity is one of the most serious environmental stresses influencing crop growth and productivity (Koca et al., 2007). The complex effects of salinity cause a reduction in the growth of which is due to osmotic effect or reduction in water absorption and specific effect of ion such as sodium and chlorine that particularly have toxic effects on fruit trees (Shani and Ali, 2005 and Marandi et al., 2009). The osmotic effect on growth is proportional to decrease in the osmotic potential of the soil solution, operates from low values of soil salinity, and reduces leaf water potential, transpiration and photosynthesis (Jaleel et al., 2007 and Khan and Panda, 2008).

Calcium supply to the saline soil solution regulates $\mathrm{Na}^{+}$uptake by plants. It can prevent the accumulation of toxic levels of $\mathrm{Na}^{+}$(Maas, 1993). Calcium plays an essential role in processes that preserve the structural and functional integrity of plant membranes, stabilize cell wall structures, regulate ion transport and selectivity, and control ion-exchange behavior as well as cell wall enzyme activities (Marschner, 1995).

Plant tissue culture provides useful information to elucidate response of salt stress; because in vitro conditions are more controllable than in vivo conditions and the large number of genotype can be evaluated in a limited space (Shiyab et al., 2003; Shatnawi, 2006; Cavagnaro et al. 2006 and Molassiotis et al., 2006).

Research results of grape cultivars showed that with increasing concentrations of $\mathrm{NaCl}$ in the culture medium caused a reduction of vegetative growth (El-Sabrout 2003; Charbaji and Ayyoubi 2004; Moham- madkhani et al., 2012 and Bybordi, 2012). However, application of $\mathrm{CaCl}_{2}$ treatments counteracted this inhibitory effect of growth parameters (Sotiropoulos, 2007 on M4 apple rootstock; Lolaei et al., 2012 on olive; Arshi et al., 2005 on senna (Cassia angustifolia) and Amuthavalli et al., 2012 on cotton. In addition, increasing $\mathrm{NaCl}$ and $\mathrm{CaCl}_{2}$ concentrations in the culture medium under in vitro conditions caused increased concentration of $\mathrm{Na}$ and $\mathrm{Ca}$ in plantlets, whereas $\mathrm{K}$ concentration decreased in comparison to the control (El-Sabrout, 2003; Alizadeh et al., 2010; Sivritepe et al., 2010; Bybordi, 2012; Karimi and YusefZadeh, 2013).

The present study aimed to in vitro evaluation for salt tolerance of some grape cultivars via study the effects of salinity on the morphological and biochemical aspects in the tested cultivars.

\section{Materials and Methods:}

The present experiment started on 2010 year and ended on 2014, at fruit crops orchard and tissue culture laboratory, Fruit Department, Faculty of Agriculture, Assiut University, to study the tolerance of three grape cultivars (Red Roomy, Thomson Seedless, and Beauty Seedless) to salt stress against different types and levels of salts $\left(\mathrm{NaCl}, \mathrm{CaCl}_{2}\right)$.

Shoot tip explants $(0.5-1.0 \mathrm{~cm}$ long) of three grape cultivars were cultured on (MS) Murashige and Skoog (1962) medium supplemented with $0.1 \mathrm{mg} / 1$ benzylaminopurine (BAP), $0.01 \mathrm{mg} / 1$ 3-indol butyric acid (IBA), $1.5 \mathrm{mg} / \mathrm{l}$ gibberellic acid $\left(\mathrm{GA}_{3}\right), 30 \mathrm{~g} / 1$ sucrose, $0.1 \mathrm{~g} / 1$ myoinositol and $2.5 \mathrm{~g} / 1$ Gelrite for solidification as an establishment medium and proliferated in the same medium 
containing $1.0 \mathrm{mg} / \mathrm{l} \mathrm{BAP}$. For in vitro salt tolerance, proliferated shoots were cultured in MS medium supplemented with $\mathrm{NaCl}$ and $\mathrm{CaCl}_{2}$ solutions as follows: a) $0,50,85$ and 120 $\mathrm{mM}$ of $\mathrm{NaCl}$; b) $0,1,5$ and $10 \mathrm{mM}$ of $\mathrm{CaCl}_{2}$ and c) $0,60(50 \mathrm{NaCl}+10$ $\left.\mathrm{CaCl}_{2}\right)$ and $90\left(85 \mathrm{NaCl}+5 \quad \mathrm{CaCl}_{2}\right)$ $\mathrm{mM}$. Also, $\mathrm{pH}$ of the prepared medium was then adjusted to $5.6-5.8$ using $0.1 \mathrm{~N} \mathrm{NaOH}$ and $\mathrm{HCl}$ solutions. Medium was poured in $200 \mathrm{ml} / \mathrm{jar}$ and $25 \mathrm{ml} \mathrm{medium} / \mathrm{jar}$ then jars were autoclaved at $1.5 \mathrm{~kg} / \mathrm{cm}^{2}$ pressure and $120^{\circ} \mathrm{C}$ temperatures for 20 minutes. The jars containing medium were left to be air-cooled for solidification. Incubation of culture jars were made in culture room at temperature of $24 \pm 2^{\circ} \mathrm{C}$ under florescent light for 16 hours/day for 4-6 weeks. Each treatment consisted of 15 repetitions (15 jars). The repetitions was divided into 5 replicates, each one consisted of 3 jars (repetitions).

\section{Measurements:}

The following measurements were evaluated throughout the experimental seasons:

\section{A- Vegetative growth measure- ments:}

1. Number of proliferated shoots/ explant.

2. Length of proliferated shoot $(\mathrm{cm})$.

3. Number of leaves/shoot.

4. Number of nodes/shoot.

5. Length of internode $(\mathrm{cm})$.

6. Plantlet fresh and dry weight (g).

\section{B- Mineral composition:}

Plantlets were collected and oven-dried at $70^{\circ} \mathrm{C}$ for 48 hours. The dried plantlets were ground using Wiley mill, and acid digested using $\mathrm{H}_{2} \mathrm{O}_{2}$ and $\mathrm{H}_{2} \mathrm{SO}_{4}$ method (Parkinson and Allen, 1975). The following minerals were determined.

1. $\mathrm{Na}^{+}$and $\mathrm{K}^{+}$were determined by flame photometer method (Williams and Twine, 1960).

2. $\mathrm{Ca}^{++}$was determined by Perkin Elmer Atomic Absorption Spectrophotometer (Murphy and Riley, 1962).

The data of all minerals were expressed as $\mathrm{mg} / \mathrm{g}$ dry weight.

\section{Statistical analysis:}

The experiments were set as a factorial experiment $(3 \times 9)$ with five replicates. Means compared with the Least Significant Difference (L.S.D.) at 5\% level of probability (Steel and Torrie 1980).

\section{Results and Discussion: \\ 1-Effect of salinity on vegetative characteristics:}

Data presented in Table (1) and Fig. (2) revealed that, there were a decrease in all vegetative growth characteristics under the study accompanied with the increase in $\mathrm{NaCl}$ concentration from zero to $120 \mathrm{mM}$. On the other hand, $\mathrm{CaCl}_{2}$ has positive effect on vegetative characteristics compared to $\mathrm{NaCl}$ treatments. The data indicated that there were significant increases in growth parameters resulted from 1 to $5 \mathrm{mM} \mathrm{CaCl} 2$ concentrations compared to $10 \mathrm{mM}$ $\mathrm{CaCl}_{2}$ concentration. In addition, $\mathrm{CaCl}_{2}$ had an additive effect when using with the $\mathrm{NaCl}$.

The number of new proliferated shoots per explant was 3.9, 2.6, 2.1 and 1.5 when $\mathrm{NaCl}$ concentration was used at $0,50,85$ and $120 \mathrm{mM}$, respectively. For $\mathrm{CaCl}_{2}$, the proliferation rate was significantly increased from 1 to $5 \mathrm{mM}$ (3.7 to 4.7 , consecutively). The highest multiplication (4.8 shoot/explant) occurred when Red Roomy and Beauty Seedless cul- 
tivars were grown on MS medium supplemented with $5 \mathrm{mM} \mathrm{CaCl}_{2}$. As for conclusion, $\mathrm{CaCl}_{2}$ induced the highest proliferation rate compared to $\mathrm{NaCl}$ or the mixture of both salts. In addition, There were gradual decreases in shoot length in response to the increase of $\mathrm{NaCl}$ concentration being the maximum at $120 \mathrm{mM} \mathrm{NaCl}$ (64.7\% reduction in plantlet height). The differences among $\mathrm{NaCl}$ treatments were, statistically, significant. On the other hand, data showed insignificant increases in plantlet height resulted from 1 to $5 \mathrm{mM} \mathrm{CaCl} 2$ concentrations. In general, insignificant differences were found among Thompson Seedless and Beauty Seedless cultivars; meanwhile Red Roomy showed the highest shoot length at all salinity treatments.

The data, also, indicated that there was a significant reduction of leaves per shoot produced as a result of using $\mathrm{NaCl}$. Control treatment produced 3.8 leaf/shoot while 120 $\mathrm{mM} \mathrm{NaCl}$ produced 2.1 (44.7\% reduction) leaf/shoot. Concerning of $\mathrm{CaCl}_{2}$, the leaves number per shoot was 3.2 at $1 \mathrm{mM} \mathrm{CaCl} 2$ increased to 3.9 at $5 \mathrm{mM} \mathrm{CaCl}_{2}$. The highest number of leaves per shoot (4.3) was found in the Beauty Seedless cultivar at $5 \mathrm{mM} \mathrm{CaCl}$. The same trend was found for the number of node per shoot with the highest value of (4.2 node/shoot) for Thompson Seedless cultivar. In addition, overall $\mathrm{NaCl}$ treatments decreased internode length compared to the control; however, such decrements were not significant at 50,85 and $120 \mathrm{mM} \mathrm{NaCl}$ treatments $(0.8 v s .0 .7,0.6$ and $0.6 \mathrm{~cm}$, consecutively). Using $\mathrm{CaCl}_{2}$ mixed with $\mathrm{NaCl}$ had no effect on average internode length compared with other salinity treatments. The highest value was $1.7 \mathrm{~cm}$ for Thompson Seedless grown in MS medium supplemented with $5 \mathrm{mM} \mathrm{CaCl}_{2}$.

The data revealed that $\mathrm{NaCl}$ treatment at $50 \mathrm{mM}$ had insignificant effect on plantlet fresh weight $(2.5 \mathrm{~g})$ compared to the control $(3.2 \mathrm{~g}) . \mathrm{NaCl}$ treatments at 85 and $120 \mathrm{mM}$ significantly reduced plantlet fresh weight 2.0 and $1.5 \mathrm{~g}$, respectively compared to untreated plants. On the other hand, data in the same Table revealed that $\mathrm{CaCl}_{2}$ at $5 \mathrm{mM}$ significantly increased plantlet fresh weight $(5.4 \mathrm{~g})$ compared to the control $(3.2 \mathrm{~g})$ and 1 $\mathrm{mM} \mathrm{CaCl} 2$ (3.0 g). Generally, $\mathrm{CaCl}_{2}$ treatments induced the highest plantlet fresh weight compared to $\mathrm{NaC}$ treatmentsl. The highest value was $6.5 \mathrm{~g}$ for Red Roomy cultivar when the medium was supplemented with 5 $\mathrm{mM} \mathrm{CaCl}$. Additionally, data indicated that plantlets grown on MS medium $+\mathrm{NaCl}$ were, negatively, influenced by salinity treatments based on the plantlet dry weight. The plantlets dry weights were found to be affected as a result of the least $\mathrm{NaCl}$ treatment $(50 \mathrm{mM})$; such reduction was $19.2 \%$ increased to 34.6 and $38.5 \%$ for 85 and $120 \mathrm{mM}$, consecutively. On the opposite side, the average dry weight of the three grape cultivars insignificantly increased from 1 to $5 \mathrm{mM}$ $\mathrm{CaCl}_{2}$ compared to the control. The average plantlets dry weights were $0.26 \mathrm{~g} v s$. 0.20 and $0.26 \mathrm{~g}$, respectively. As for conclusion, $\mathrm{CaCl}_{2}$ induced the highest plantlet dry weight comparing to $\mathrm{NaCl}$ treatment or the mixture of the two salts.

The changes in morphological traits with increasing the salt concentration were reported in grape cultivars with numerous researchers (ElSabrout, 2003; Charbaji and Ayyoubi, 2004; Mohammadkhani et al., 
2012; Fozouni et al., 2012; Bybordi, 2012 and Karimi and Yusef-Zadeh, 2013). In addition, finding of Shibli et al. (2003) on almond, Naeniei et al. (2006) and El-Agamy et al. (2010) on pomegranate, Al-Darweesh (2006) on olive, Shiyab et al. (2003) and Perez-Tornero et al. (2009) on citrus and Sotiropoulos (2007), and Bahmani et al. (2012) on apple support the present data.

\section{2- Effect of salinity on nutritional status:}

Figure (1) revealed that the sodium content showed a tendency for positive response to $\mathrm{NaCl}$ treatments. Sodium contents were 2.11, 5.00, 8.02 and $12.82 \mathrm{mg} / \mathrm{g}$ dry weight when $\mathrm{NaCl}$ concentrations were used at 0 , 50, 85, and $120 \mathrm{mM}$, respectively. The differences among $\mathrm{NaCl}$ treatments were statistically significant. On the other hand, for $\mathrm{CaCl}_{2}$ treatments, there was insignificant effect among all $\mathrm{CaCl}_{2}$ treatments and the control, while using the mixture of the both salts showed a positive increase in sodium content compared to the control. Potassium content of shoots of the tested grape cultivars was greatly reduced with the increase of $\mathrm{NaCl}$ concentrations. For calcium content, the data indicated that the effect of $\mathrm{NaCl}$ treatments on calcium content showed a significant negative response. Concerning of $\mathrm{CaCl}_{2}$ treat- ments, the calcium content showed a tendency for positive response to $\mathrm{CaCl}_{2}$ treatments. Calcium contents were $4.61,5.11,6.00$ and $7.46 \mathrm{mg} / \mathrm{g}$ dry weight when $\mathrm{CaCl}_{2}$ concentrations were used at $0,1,5,10 \mathrm{mM}$, consecutively. The differences among $\mathrm{CaCl}_{2}$ treatments were statistically significant. In addition, $\mathrm{NaCl}$ mixed with $\mathrm{CaCl}_{2}$ at $60 \mathrm{mM}$, regardless of the effect of the cultivars, recorded the highest value of calcium content (11.72 mg/g dry weight) compared to all tested salinity treatments.

The results indicated that plantlets $\mathrm{Na}^{+}$content in the studied grape cultivars showed a tendency for positive response to all salinity treatments. On the contrary, $\mathrm{K}^{+}$and $\mathrm{Ca}^{2+}$ contents of shoots of the tested grape cultivars were reduced with the increase of $\mathrm{NaCl}$ concentrations, while using $\mathrm{CaCl}_{2}$ induced increased in $\mathrm{K}$ and $\mathrm{Ca}$ contents. These results were in agreement with those reported by several authors (Troncoso et al., 1999, El-Sabrout, 2003, Sivritepe et al., 2010, and Bybordi, 2012) on grape, Shibli et al. (2003) on almond; Naeniei et al.(2006) and El-Agamy et al. (2010) on pomegranate; Sotiropoulos (2007) on apple rootstocks M4 and Habibi and Amiri (2013) on citrus but in disagreement with Alizadeh et al. (2010) on grape and Ahmed et al. (2005) on citrus. 
Table (1): Effect of salinity on vegetative growth characteristics of some grape cultivars.

\begin{tabular}{|c|c|c|c|c|c|c|c|c|c|c|c|c|}
\hline \multirow{2}{*}{ 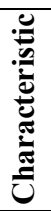 } & \multirow{2}{*}{ Treatment (B) } & \multirow{2}{*}{$\begin{array}{c}\text { 0.0 } \\
\text { Control }\end{array}$} & \multicolumn{3}{|c|}{$\mathbf{m M ~ N a C l}$} & \multicolumn{3}{|c|}{$\mathrm{mM} \mathrm{CaCl} 2$} & \multicolumn{2}{|c|}{ mM Mix } & \multirow{2}{*}{$\begin{array}{c}\text { Cultivar } \\
\text { mean }\end{array}$} & \multirow{2}{*}{$\begin{array}{c}\text { L.S.D. } \\
\mathbf{5 \%}\end{array}$} \\
\hline & & & 50 & 85 & 120 & 1 & 5 & 10 & 60 & 90 & & \\
\hline \multirow{4}{*}{ 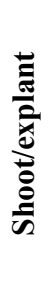 } & Thompson Seedless & 4.2 & 2.6 & 2.2 & 1.4 & 3.8 & 4.6 & 2.8 & 2.8 & 1.4 & 2.9 & \multirow{4}{*}{$\begin{array}{c}\mathrm{A}=\mathrm{N} . \mathrm{S} \\
\mathrm{B}=0.4 \\
\mathrm{AB}=\mathrm{N} . \mathrm{S} \\
\mathrm{T}=0.8\end{array}$} \\
\hline & Red Roomy & 4.0 & 2.8 & 2.0 & 1.4 & 4.0 & 4.8 & 2.4 & 3.0 & 1.2 & 2.8 & \\
\hline & Beauty Seedless & 3.4 & 2.4 & 2.2 & 1.6 & 3.4 & 4.8 & 2.6 & 2.6 & 1.2 & 2.7 & \\
\hline & Treatment mean & 3.9 & 2.6 & 2.1 & 1.5 & 3.7 & 4.7 & 2.6 & 2.8 & 1.3 & & \\
\hline \multirow{4}{*}{ 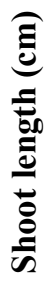 } & Thompson Seedless & 3.0 & 2.6 & 1.9 & 1.4 & 2.4 & 2.4 & 2.2 & 1.9 & 1.5 & 2.1 & \multirow{4}{*}{$\begin{array}{c}\mathrm{A}=0.1 \\
\mathrm{~B}=0.2 \\
\mathrm{AB}=0.3 \\
\mathrm{~T}=0.3\end{array}$} \\
\hline & Red Roomy & 3.4 & 2.8 & 2.6 & 1.5 & 2.4 & 2.5 & 2.3 & 2.0 & 1.7 & 2.3 & \\
\hline & Beauty Seedless & 3.7 & 2.7 & 2.2 & 0.7 & 2.2 & 2.6 & 1.6 & 1.3 & 1.3 & 2.0 & \\
\hline & Treatment mean & 3.4 & 2.7 & 2.2 & 1.2 & 2.4 & 2.5 & 2.0 & 1.7 & 1.5 & & \\
\hline \multirow{4}{*}{ 泀 } & Thompson Seedless & 3.7 & 3.3 & 2.5 & 2.0 & 3.5 & 3.6 & 2.5 & 2.4 & 1.8 & 2.8 & \multirow{4}{*}{$\begin{array}{c}\mathrm{A}=0.1 \\
\mathrm{~B}=0.3 \\
\mathrm{AB}=0.4 \\
\mathrm{~T}=0.4\end{array}$} \\
\hline & Red Roomy & 3.7 & 3.3 & 3.1 & 2.2 & 3.1 & 3.8 & 2.9 & 2.6 & 2.0 & 3.0 & \\
\hline & Beauty Seedless & 4.1 & 3.3 & 3.0 & 2.2 & 3.1 & 4.3 & 3.4 & 2.6 & 1.8 & 3.1 & \\
\hline & Treatment mean & 3.8 & 3.3 & 2.9 & 2.1 & 3.2 & 3.9 & 3.0 & 2.5 & 1.9 & & \\
\hline \multirow{4}{*}{ 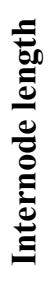 } & Thompson Seedless & 0.8 & 0.6 & 0.6 & 0.8 & 0.7 & 1.7 & 0.7 & 0.7 & 0.7 & 0.8 & \multirow{4}{*}{$\begin{array}{c}\mathrm{A}=0.2 \\
\mathrm{~B}=0.4 \\
\mathrm{AB}=\mathrm{N} . \mathrm{S} \\
\mathrm{T}=0.6\end{array}$} \\
\hline & Red Roomy & 0.8 & 0.8 & 0.7 & 0.6 & 0.9 & 0.7 & 0.7 & 0.7 & 0.6 & 0.7 & \\
\hline & Beauty Seedless & 0.9 & 0.6 & 0.6 & 0.4 & 0.8 & 0.6 & 0.5 & 0.4 & 0.3 & 0.6 & \\
\hline & Treatment mean & 0.8 & 0.7 & 0.6 & 0.6 & 0.7 & 1.0 & 0.6 & 0.6 & 0.6 & & \\
\hline \multirow{4}{*}{ 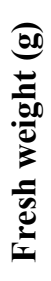 } & Thompson Seedless & 3.1 & 2.9 & 2.5 & 1.9 & 3.0 & 5.3 & 3.4 & 3.2 & 1.9 & 3.0 & \multirow{4}{*}{$\begin{array}{c}\mathrm{A}=0.4 \\
\mathrm{~B}=0.6 \\
\mathrm{AB}=1.0 \\
\mathrm{~T}=1.0\end{array}$} \\
\hline & Red Roomy & 3.2 & 2.5 & 1.7 & 1.5 & 2.8 & 6.5 & 4.0 & 3.5 & 2.1 & 3.1 & \\
\hline & Beauty Seedless & 3.3 & 2.2 & 1.9 & 1.1 & 3.3 & 4.4 & 1.8 & 3.6 & 1.5 & 2.6 & \\
\hline & Treatment mean & 3.2 & 2.5 & 2.0 & 1.5 & 3.0 & 5.4 & 3.1 & 3.4 & 1.8 & & \\
\hline \multirow{4}{*}{ 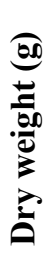 } & Thompson Seedless & 0.23 & 0.25 & 0.19 & 0.14 & 0.22 & 0.19 & 0.18 & 0.19 & 0.20 & 0.20 & \multirow{4}{*}{$\begin{array}{c}\mathrm{A}=\mathrm{N} . \mathrm{S} \\
\mathrm{B}=0.04 \\
\mathrm{AB}=0.07 \\
\mathrm{~T}=0.07\end{array}$} \\
\hline & Red Roomy & 0.28 & 0.18 & 0.13 & 0.17 & 0.14 & 0.27 & 0.21 & 0.25 & 0.15 & 0.20 & \\
\hline & Beauty Seedless & 0.27 & 0.20 & 0.20 & 0.16 & 0.23 & 0.31 & 0.18 & 0.29 & 0.11 & 0.22 & \\
\hline & Treatment mean & 0.26 & 0.21 & 0.17 & 0.16 & 0.20 & 0.26 & 0.19 & 0.24 & 0.15 & & \\
\hline
\end{tabular}

$\mathrm{T}$ dunnett $=$ the differences between control and each treatment were tested by Dunnett test 


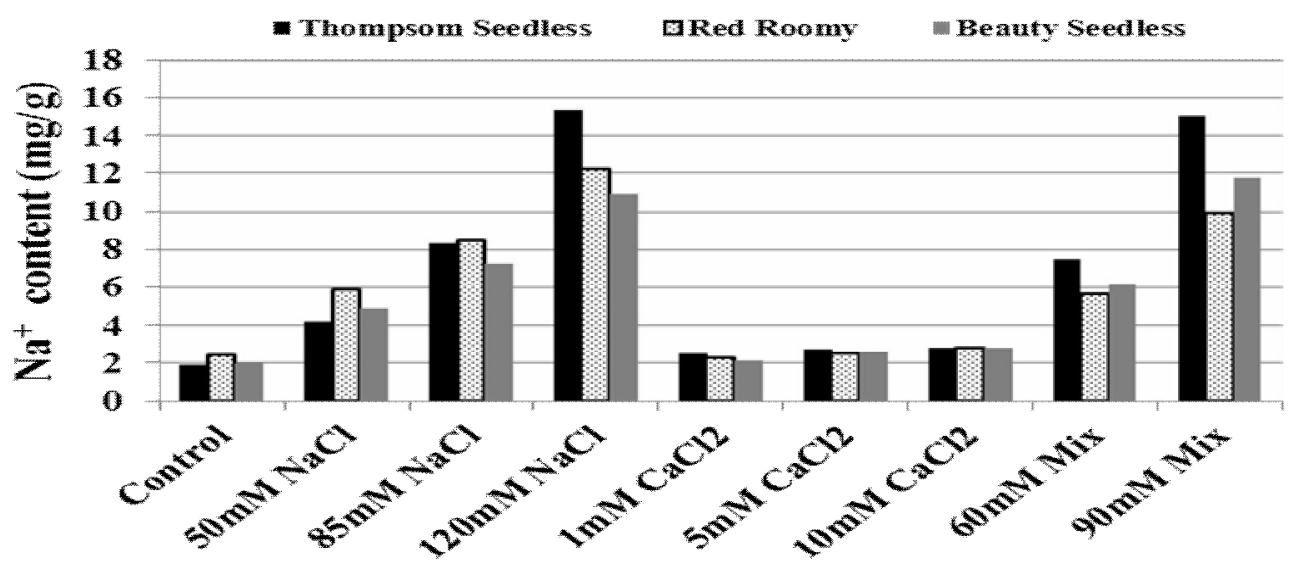

(A)

Salinity treatments
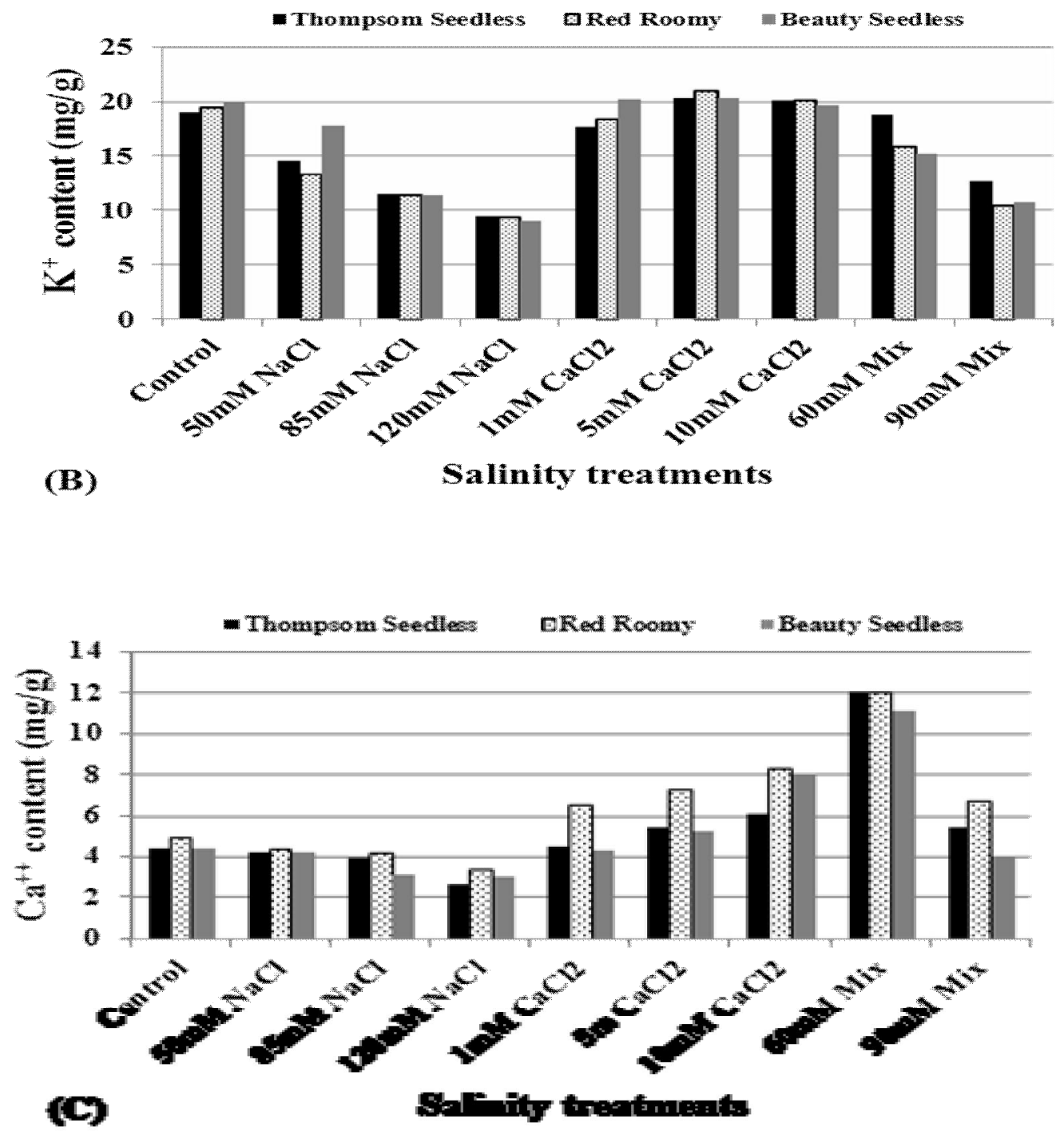

Fig. (1): Effect of salinity on nutritional status. A) Sodium content, B) Potassium content and C) Calcium content ( $\mathrm{mg} / \mathrm{g}$ dry weight). 


\section{A) Thompson Seedless}

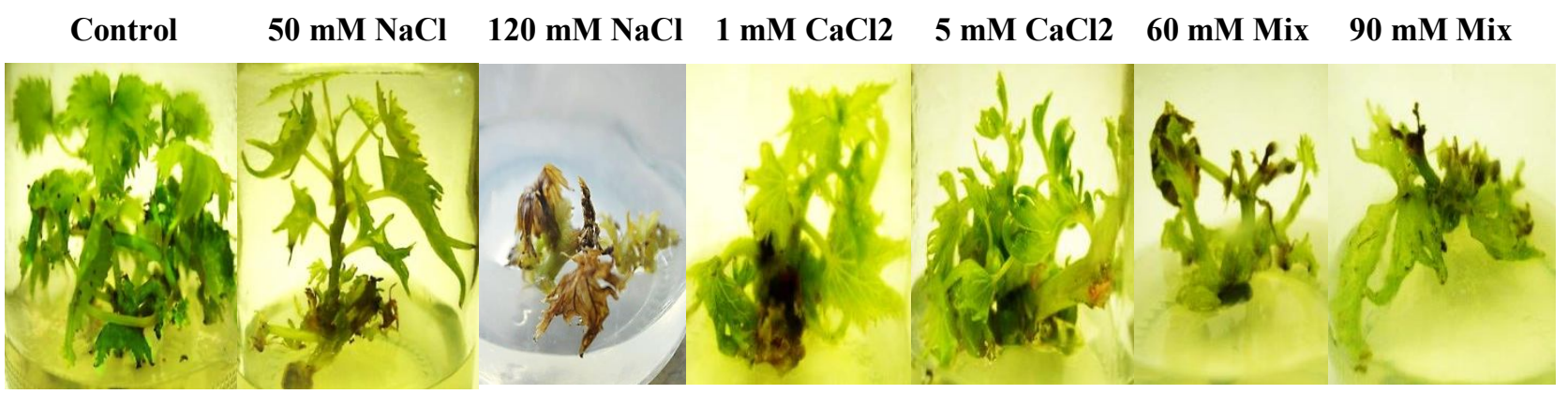

\section{B) Red Roomy}

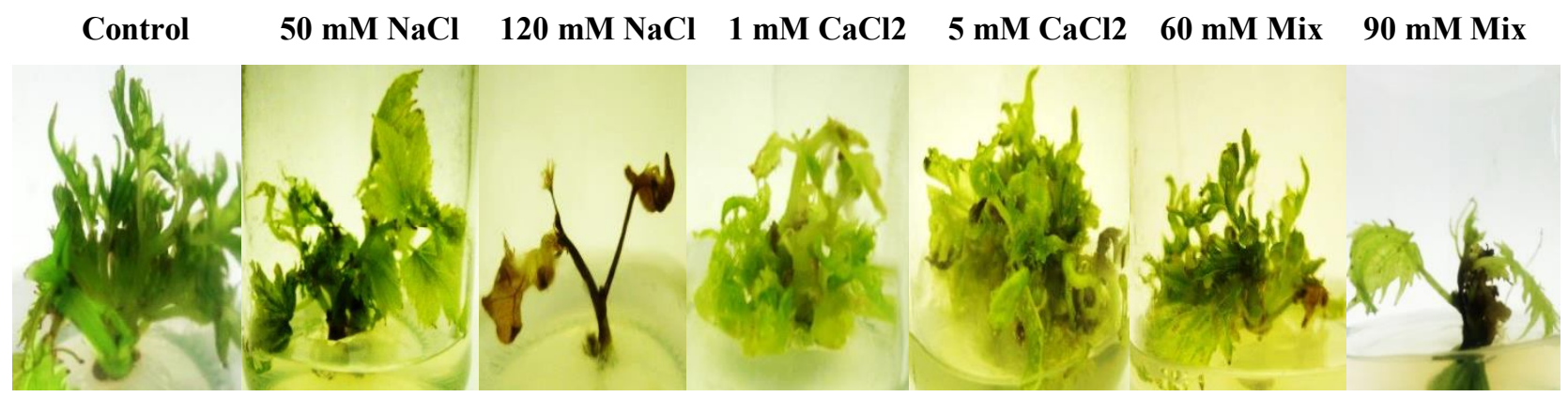

C) Beauty Seedless

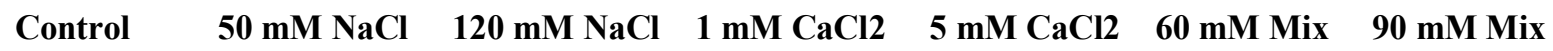

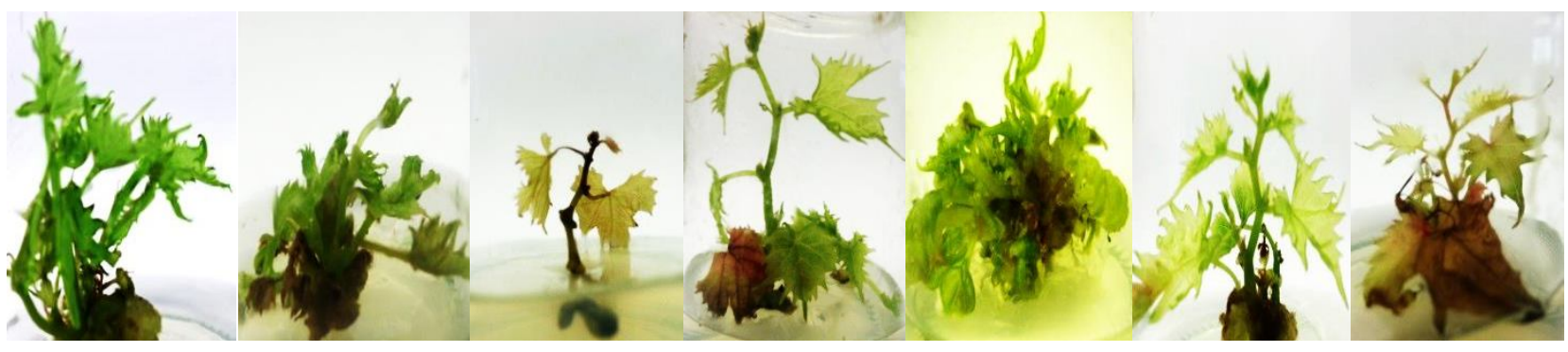

Fig. (2): Growth comparison of three grape cultivars (A- Thompson Seedless, B- Red Roomy and C- Beauty Seedless) explants grown on MS medium supplemented with different levels of salinity.

\section{References:}

Ahmed, F.F., M.Y. Hegab and S.A.G. El-Saida, 2005. Studied on effect of six citrus rootstocks on Valencia orange seedlings under soil salinity conditions. Minufiy J. Agric. Res. 30 (1): 329-340.

Al-Darweesh, M.H., 2006. Genetic improvement in olives by hybridization and in Vitro Gamma Mutation techniques. Ph.D. Dissertation, Cairo University, Cairo, Egypt.

Alizadeh, M., S.K. Singh, V.B. Patel, R.C. Bhattacharya and B.P.
Yadav, 2010. In vitro responses of grape rootstocks to $\mathrm{NaCl}$. Biologia Plantarum 54 (2): 381-385.

Amuthavalli, P., D. Anbu and S. Sivasankaramoorthy, 2012. Effect of calcium chloride on growth and biochemical constituents of cotton (Gossypium hirsutum L.) under salt stress. International Journal of Research in Botany 2 (3): 9-12.

Arshi, A., M.Z. Abdin and M. Iqbal, 2005. Ameliorative effects of $\mathrm{CaCl}_{2}$ on growth, ionic relations, and proline content of Senna un- 
der salinity stress. Journal of Plant Nutrition 28 (1): 101-125.

Bahmani, R., M. Gholami, A. Mozafari and R. Alivaisi, 2012. Effects of salinity on in vitro shoot proliferation and rooting of apple rootstock MM.106. World Applied Sciences Journal 17 (3): 292-295.

Bybordi, A., 2012. Study effect of salinity on some physiologic and morphologic properties of two grape cultivars. Life Science Journal 9 (4): 1092-1101.

Cavagnaro, J.B., M.T. Ponce, J. Guzman and M.A. Cirrincione, 2006. Argentinean cultivars of $\mathrm{Vi}$ tis vinifera grow better than European ones when cultured in vitro under salinity. Biocell 30 (1): 1-7.

Charbaji, T. And Z. Ayyobi, 2004. Defferential growth of some grapevine varieties in Syria in response to salt in vitro. In vitro Cellular\& Developmental Biology-Plant 40 (2): 221-224.

El-Agamy, S.Z., R.A.A. Mostafa, M.M. Shaaban and M.T. El-Mahdy, 2010. In vitro salt and drought tolerance of Manfalouty and Nab ElGamal pomegranate cultivars. Australian Journal of Basic and Applied Scciences 4 (6): 1076 1082.

El-Sabrout, M. B., 2003. Micropropagation and salt tolerance evaluation in some grape cultivars 11Salt tolerance evaluation. J. Agric. Sci. Mansoura Univ. 28 (11): 6833-6855.

Fozouni, M., N. Abbaspour and H.D. Baneh, 2012. Leaf water potential, photosynthetic pigments and compatible solutes alterations in four grape cultivars under salinity. Vitis 51 (3): 147-152.

Habibi, F., M.E. Amiri, 2013. Influence of in vitro salinity on growth, mineral uptake and physiological responses of two citrus rootstocks. International journal of Agronomy and Plant Production 4 (6): 1320 1326.

Jaleel, C.A., R. Gopi, P. Manivannan and R. Panneerselvam, 2007. Antioxidative potentials as a protective mechanism in (Catharanthus roseus L.) plants under salinity stress. Turkish Journal of Botany 31: 245-251.

Karimi, H. and H. Yusef-Zadeh, 2013. The effect of salinity level on the morphological and physiological Traits of two grape (Vitis vinifera L.) cultivars. International journal of Agronomy and Plant Production, 4 (5): 1108-1117.

Khan, M.H. and S.K. Panda, 2008. Alterations in root lipid peroxidation and antioxidative responses in two rice cultivars under $\mathrm{NaCl}$-salinity stress. Acta Physiologiae Plantarum, 30: 91-89.

Koca, M., M. Bor, F. Ozdemir and I. Turkan, 2007. The effect of salt stress on lipid peroxidation, antioxidative enzymes and proline content of sesame cultivars. Environ. Exp. Bot. 60:344-351.

Lolaei, A., M.A. Rezaei, M.K. Raad and B. Kaviani, 2012. Effects of salinity and calcium on the growth, ion concentration and yield of olive (Olea europaea L.) trees. Annals of Biological Research 3 (10): 4675-4679.

Maas, E. V., 1993. Salinity and citriculture. Tree Physiol. 12, 195-216.

Marandi, J.R., P.J. Doostali and R. Hassani, 2009. Studying the tolerance of two apple roots to different concentrations of sodium chloride inside the glass. The Magazine of Horticulture Science in Iran 40 (2).

Marschner, H., 1995. Mineral Nutrition of Higher Plants, $2^{\text {nd }}$ ed. Academic Press, London Pp. 18-30, 313363.

Mohammadkhani, N., R. Heidari, N. Abbaspour and F. Rahmani, 2012. 
Growth responses and aquaporin expression in grape genotypes under salinity. Iranian Journal of Plant Physiology 2 (4): 497-507.

Molassiotis, A.N., T. Sotiropoulos, G. Tanou, G. Kofidis, G. Diamantidis and I. Therios, 2006. Antioxidant and anatomical responses in shoot culture of the apple rootstock MM 106 treated with $\mathrm{NaCl}, \mathrm{KCl}$, mannitol or sorbitol. Biol. Plant 50: 61-68.

Murashige, T. and F. Skooge, 1962. A revised medium for rapid growth and bioassays with tobacco tissue cultures. Physiologia Plantarum 15: 473-497.

Murphy, J. and J.P. Riley, 1962. A modified single solution method for the determination of phosphorus in natural water. Anal. Chem. Acte 27: 31-36.

Naeniei, M., A. Khoshgoftarmanesh and E. Fallahi, 2006. Partitioning of chlorine, sodium, and potassium and shoot growth of three pomegranate cultivars under different levels of salinity. Journal of Plant Nutrition 29 (10): 1835 1843.

Parkinson, I.A. and S.E. Allen, 1975. A wet oxidation procedure suitable for the oletermination of nitrogen and mineral nutrients in biological material. Commun-Soil Sci. and Plant Analysis 6 (1): 1-11.

Perez-Tornero, O., C.I. Tallon, I. Porras and J.M. Navarro, 2009. Physiological and growth changes in micropropagated Citrus macrophlla explants due to salinity. Journal of Plant Physiology 166: 1923-1933.

Shani, U. and B. Ali, 2005. Long-term response of grapevines to salinity: Osmotic effects and ion toxicity. Am. J. Enol. Vitic. 56: 148-154.

Shatnawi, M.A., 2006. Micropropagation and germplasm storage of
Prunus amygdalus by the vitrification method. Jordan J. Agri. Sci. 2 (3): 222-233.

Shibli, R.A., M.A. Shatnawi and I.Q. Swaidat, 2003. Growth, osmotic adjustment, and nutrient acquisition of bitter almond under induced sodium chloride salinity in vitro. Communications in Soil Science and Plant Analysis 34: 19691979.

Shiyab, M.S., R.A. Shibli, and M.M. Mohammad, 2003. Influence of sodium chloride salt stress on growth and nutrient acquisition of sour orange in vitro. Journal of Plant Nutrition 26 (5): 985-996.

Sotiropoulos T. E., 2007. Effect of $\mathrm{NaCl}$ and $\mathrm{CaCl}_{2}$ on growth and contents of minerals, chlorophyll, proline and sugars in the apple rootstock M4 cultured in vitro. Biologia Plantarum 51 (1): 177180.

Steel, R.G. and J.H. Torrie, 1980. Principles and procedures of statistics $2^{\text {nd }}$ ed. Mc Graw Hill Book Company, New York, USA pp. 183193.

Sivritepe, N., H.Ö. Sivritepe, H. Celik and A.V. Katkat, 2010. Salinity responses of grafted grapevines: effects of scion and rootstock genotypes. Not. Bot. Hort. Agrobot. Cluj 38 (3): 193-201.

Troncoso, A., C. Matte, M. Cantos and S. Lavee, 1999. Evaluation of salt tolerance of in vitro-grown grapevine rootstocks varieties. Vitis 38 (2): 55-60.

Williams, V. and S. Twine, 1960. Flame photometric method for sodium, potassium and calcium. In modern methods of plant analysis by Peach, k. and M.V. Tracey. Springer-Verlag Berlin 56: 6-12. 


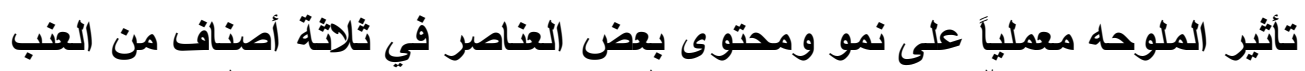

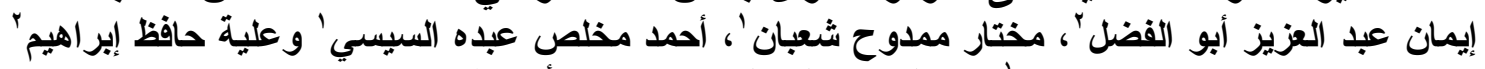

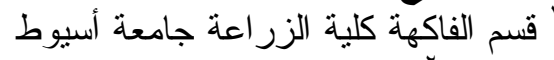

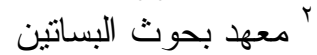

(الملخص:

تمت در اسة تأثثر الملوحة معمليا في صورة كلوريد الصوديوم وكلوريد الكالـسيوم علـىى نمو و المحتوى من العناصر لثاثثة أصناف من العنب (البيوتي سيدلس و الرومي الأحمر و البناتي الأبيض). تمت زر اعة الأجز اء النباتية المنفصلة للقمم النامية لتلك الأصناف الثلاثة علــى بيئـة مور اثتيجي وسكوج المحتوية على تركيز املجم/لتز من البنزيل أمينوبيورين. تم تتفيذ التجربــة

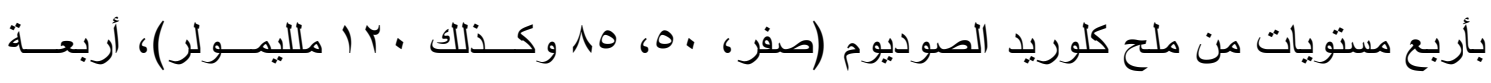
مستويات من ملح كلوريد الكالسيوم (صفر، (، 0 وكذلك ، 1 ملليمولر) وكذللك مخــاليط لكـال الملحين في ثناثة مستويات (صفر ، ج، 9 ملليمولر). أوضحت النتائج أن صفات النمو (معدل التفريع، طول النبيتات، متوســـ عـدد الأوراق، عدد العقد، طول السلامية، الوزن الطاز ج و الجاف) قد تتاقصت بــصورة معنويــة مـــع زيــادة تركيز ات كلوريد الصوديوم حتى • r ا ملليمولر مقارنة بالمعاملة القياسية. كما أوضحت النتائج،

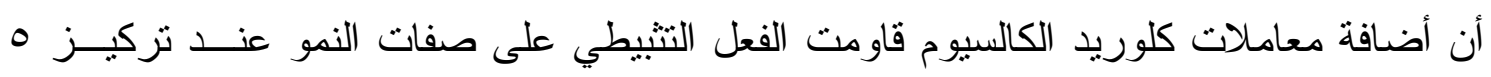
ملليمولر. كما أن أضافة كلوريد الكالسيوم أدى إلى زيادة المحتوى من أيونات الكالسيوم و انقص

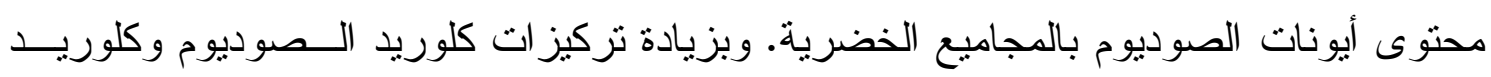

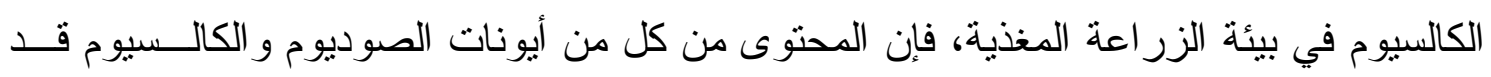
أزدادت، بينما قل المحتوى من أيونات البوتاسيوم مقارنة بالمعاملة القياسية. 